\title{
Otomasi Pendorong Singkong pada Mesin Pemotong dalam Pembuatan Keripik Singkong
}

\author{
Reinol Silitonga and Muhammad Arifin* \\ Politeknik Negeri Batam, Batam, Indonesia \\ "Email: arifin@polibatam.ac.id
}

\begin{abstract}
Mesin pemotong singkong otomatis merupakan suatu mesin yang dirancang untuk memotong singkong secara otomatis dengan memanfaatkan komponen elektronika. Hasil potongan singkong dapat dimanfaatkan sebagai makanan ringan salah satunya adalah kripik singkong. Dalam perancangan alat pemotong singkong ini dibutuhkan power supply $12 \mathrm{VDC}$ sebagai penyuplai tegangan, motor power window sebagai pendorong singkong, motor kapasitor sebagai penggerak mata pisau, push button dan limit switch sebagai saklar pengaktifan komponen. Mesin ini dikontrol dengan meggunakan relay, sedangkan potensiometer digunakan dalam menentukan kelajuan pendorong singkong. Pengukuran tebal atau tipisnya hasil pemotongan diukur menggunakan jangka sorong. Hasil pemotongan singkong optimal didapat pada hambatan potensiometer $1000 \mathrm{k} \Omega$ dan durasi waktu 12 menit untuk 3 kg singkong dengan ketebalan pemotongan $4 \mathrm{~mm}$.
\end{abstract}

Kata kunci : Otomasi, mesin pemotong singkong, kripik singkong

\section{PENDAHULUAN}

Berdasarkan hasil survei yang dilakukan di industri rumahan keripik singkong yang ada di Batam dan sekitarnya diketahui bahwa kebanyakan proses pemotongan singkongnya masih manual sehingga kurang efisiens dan produktivitas cukup rendah. Untuk miningkatkan efisiensi dan produktivitas tersebut maka perlu adanya otomasi pada alat pemotong singkong.

Alat pemotong singkong otomatis sudah pernah dibuat oleh Winandar, dkk [1], Hermanto, dkk [2], Magdalena, dkk [3], dan Hidayatullah, dkk [4]. Rancang bangun mesin pemotong singkong yang dibuat oleh Magdalena, dkk masih ada beberapa kekurangan, salah satunya yaitu tidak adanya mekaniskme penekanan pada singkong yang akan ditekan. Penekanan pada singkong masih manual yaitu menggunakan tangan [3]. Mekanisme penekanan atau pendorongan singkong secara manual ini bisa membutuhkan waktu yang agak lama sehingga kurang efisien dalam prosesnya. Selain itu, cara manual tersebut juga berbahaya bagi penggunanya karena bisa jadi tangan pengguna terkena pisau

Berdasarkan permasalahan tersebut, penulis perlu merancang mesin pemotong singkong otomatis dengan mengubah bentuk alat dan mengotomatiskan pendorong singkong ke mata pisau sehingga lebih efisien dan diharapkan dapat menghasilkan potongan singkong yang sesuai untuk dibuat keripik singkong.

\section{METODE}

Sistem perancangan dalam penelitian ini dilakukan dengan melalui beberapa tahapan yaitu pembuatan rangkaian elektronik, desain mekanik, perancangan mesin, dan pengukuran. Dalam penelitian ini massa singkong yang digunakan adalah $3 \mathrm{~kg}$.

\section{A. Pembuatan Rangkaian Elektronik}

Pada penelitian ini terdapat rangkaian pengontrol yang digunakan untuk mengontrol motor pendorong singkong supaya dapat bekerja sesuai dengan yang ditentukan dengan menggunakan limitswitch dan relay. Adapun rangkain elektronik yang digunakan sesuai yang ada pada Gambar 1.

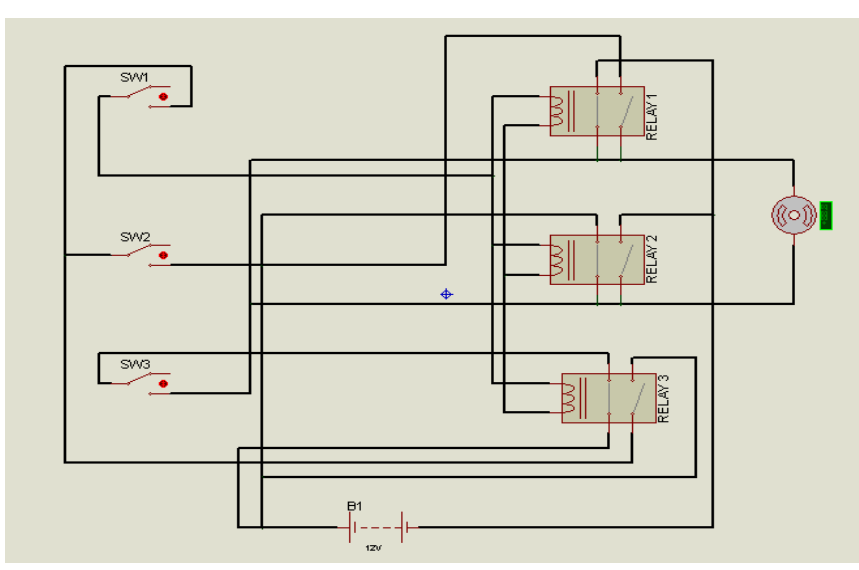

Gambar 1. Desain rangkaian elektronika motor power window. 
Power supply sebagai sumber tegangan untuk mengaktifkan limitswitch dan relay yang mensuplai tegangan sebesar 12 volt untuk menghidupkan motor power window. Fungsi relay sebagai pengontrol power window sedangkan fungsi motor power window sebagai pendorong dan fungsi limitswitch sebagai pembalik polaritas motor power window. Perancangan rangkaian elektronik ini juga mengacu pada teori-teori mendasar pada elektronika [5].

\section{B. Pembuatan Desain Mekanik}

Desain mekanik dibuat untuk mengetahui bentuk mesin yang akan dirancang. Mesin tersebut akan digunakan sebagai tempat pemotongan singkong dan penempatan komponenkomponen elektronika yang akan digunakan. Pada mesin tersebut terdapat empat buah pendorong yang akan mendorong singkong kemata pisau, empat buah corong yang berfungsi sebagai penahan singkong pada saat proses pemotongan dan satu buah mata pisau pemotong yang akan memotong singkong sekaligus dari keenam jalur tesebut. Desain mekanik mesin seperti yang ditunjukkan pada Gambar 2.
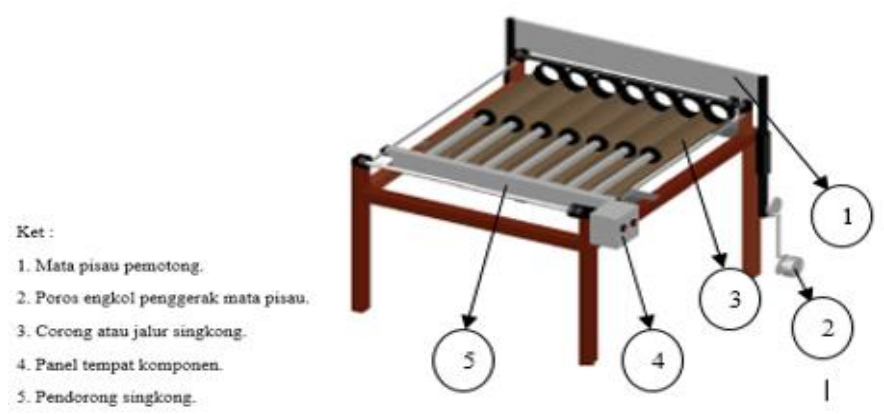

Gambar 2. Desain Mekanik Mesin Pemotong Singkong.

\section{Perancangan Mesin}

Proses pengerjaan penelitian ini melalui beberapa tahap. Ada beberapa tahap dalam melakukan proses pembuatan mesin ini. Dalam perancangan suatu sistem, dibutuhkan blok diagram yang dapat menerangkan sistem secara keseluruhan agar sistem yang dibuat dapat berjalan sebagaimana yang diinginkan seperti yang ditunjukkan pada Gambar 3.

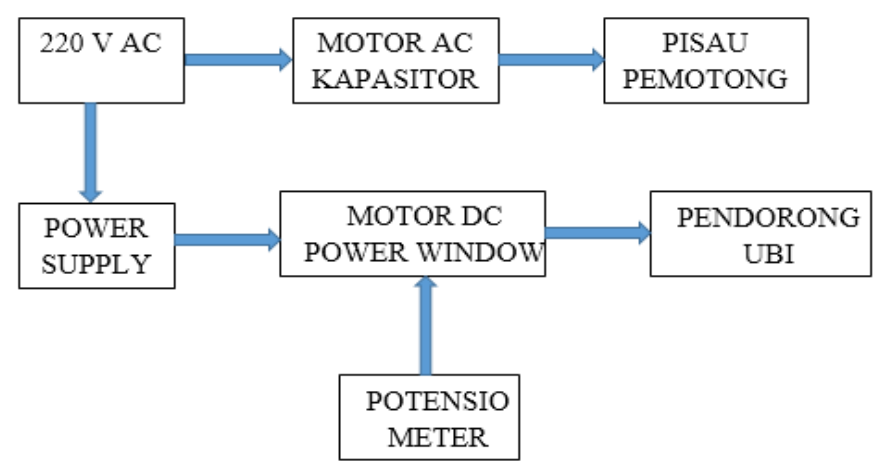

Gambar 3. Diagram blok sistem pada mesin pemotong singkong.
Tegangan AC $220 \mathrm{~V}$ adalah sebagai penyuplai energi listrik ke komponen-komponen yang digunakan dalam alat pemotong singkong. Tegangan AC akan dialirkan langsung ke komponen yang menggunakan tegangan $\mathrm{AC}$ seperti motor $\mathrm{AC}$ kapasitor dan power supply. Motor AC kapasitor ini berfungsi sebagai penggerak mata pisau pemotong singkong. Sedangkan power supply berfungsi sebagai penyearah tegangan AC menjadi tegangan DC. Push button berfungsi sebagai saklar yang dapat memutus dan menyambungkan tegangan AC dari input $220 \mathrm{~V}$ AC. Potensiometer sebagai pengontrol kelajuan pendorong singkong. Limit switch berfungsi sebagai saklar yang menyalurkan tegangan DC dengan sistem kerja secara penguncian dengan memanfaatkan koil dari relay sebagai pengunci tegangan. Relay berfungsi sebagai pengontrol motor dc power window.

\section{Pengukuran}

Instrument yang digunakan pada penelitian ini adalah multimeter dan jangka sorong. Multimeter digunakan untuk mengetahui tegangan atau arus yang ada pada rangkaian sedangkan jangka sorong digunakan untuk mengukur ketebalan singkong yang sudah dipotong.

\section{HASIL DAN DISKUSI}

Eksperimen dilakukan sebanyak 5 kali dengan massa singkong $3 \mathrm{~kg}$ tiap eksperimen. Pemotongan berhasil jika motor pendorong sinkron dengan motor pemotong dan pemotongan tidak berhasil jika motor pendorong dan motor pemotong tidak sinkron. Data hasil pemotongan singkong ditunjukkan pada Tabel 1.

TABEL 1

HASIL PEMOTONGAN SINGKONG

\begin{tabular}{ccccc}
\hline No. & $\begin{array}{c}\text { Panjang } \\
\text { Singkong } \\
(\mathrm{cm})\end{array}$ & $\begin{array}{c}\text { Hambatan } \\
\text { Potensio } \\
(\mathrm{k} \Omega)\end{array}$ & $\begin{array}{c}\text { Waktu } \\
\text { Pemotongan } \\
(\text { menit })\end{array}$ & $\begin{array}{c}\text { Ketebalan } \\
\text { Singkong } \\
\text { setelah } \\
\text { Pemotongan } \\
(\mathrm{mm})\end{array}$ \\
\hline 1 & 20 & 600 & 4 & 15 \\
2 & 20 & 700 & 5 & 10 \\
3 & 20 & 800 & 7 & 8 \\
4 & 20 & 900 & 9 & 5 \\
5 & 20 & 1000 & 12 & 4 \\
\hline
\end{tabular}

Hasil pengukuran menunjukkan bahwa bahwa semakin besar hambatan potensiometer maka tegangan keluaran akan semakin kecil seperti yang ditunjukkan pada Tabel 2. Tegangan keluaran tersebut akan digunakan untuk mempercepat atau memperlambat kelajuan motor pendorong. Semakin besar hambatan potensiometer maka kecepatan motor pendorong akan semakin melambat. 
TABEL 2

HASIL PENGUKURAN TEGANGAN OUTPUT

\begin{tabular}{cccc}
\hline No. & $\begin{array}{c}\text { Tegangan Input } \\
\text { (Volt) }\end{array}$ & $\begin{array}{c}\text { Hambatan } \\
\text { Potensio }(\mathrm{k} \Omega)\end{array}$ & $\begin{array}{c}\text { Tegangan Output } \\
\text { (Volt) }\end{array}$ \\
\hline 1 & 12 & 600 & 10 \\
2 & 12 & 700 & 9,5 \\
3 & 12 & 800 & 7 \\
4 & 12 & 900 & 6,5 \\
5 & 12 & 1000 & 5 \\
\hline
\end{tabular}

Tabel 2 memperlihatkan hasil pengukuran tegangan output untuk motor pendorong singkong. Potensiometer diputar pada posisi $600 \mathrm{k} \Omega$ berfungsi untuk mengurangi tegangan dari power supply ke motor sehingga kelajuan motor pendorong singkong menjadi lambat, tetapi masih melebihi kecepatan motor pemotong singkong. Ketebalan singkong yang dihasilkan sebesar $15 \mathrm{~mm}$ dengan total waktu pemotongan 4 menit. Hasil potongan singkong diperlihatkan pada Gambar 4.

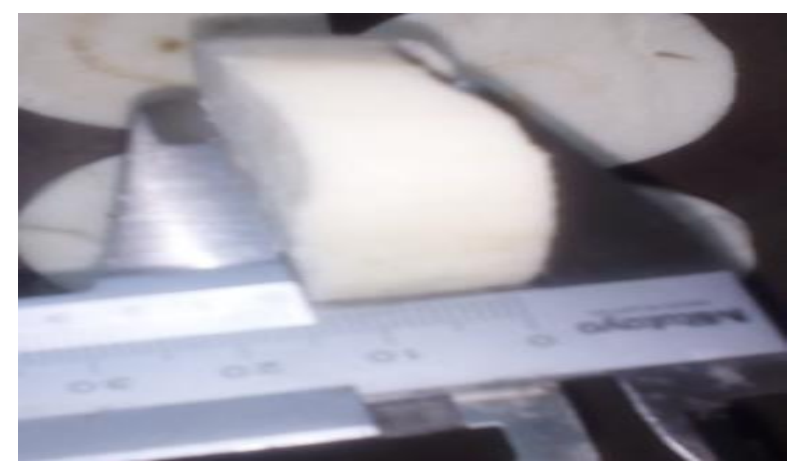

Gambar 4. Hasil pemotongan singkong untuk hambatan $600 \mathrm{k} \Omega$.

Potensiometer diputar pada posisi $700 \mathrm{k} \Omega$ berfungsi untuk mengurangi tegangan dari power supply ke motor sehingga kelajuan motor pendorong singkong menjadi lambat, tetapi kelajuan motor pendorong masih melebihi motor pemotong singkong. Ketebalan singkong yang dihasilkan sebesar $10 \mathrm{~mm}$ dengan total waktu pemotongan 5 menit. Hasil potongan singkong diperlihatkan pada Gambar 5.

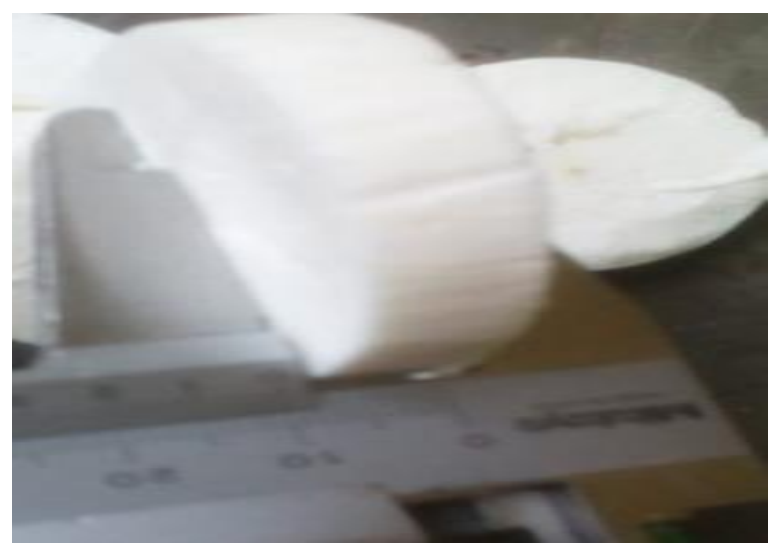

Gambar 5. Hasil pemotongan singkong untuk hambatan $700 \mathrm{k} \Omega$.
Potensiometer diputar pada posisi $800 \mathrm{k} \Omega$ berfungsi untuk mengurangi tegangan dari power supply ke motor sehingga kelajuan motor pendorong singkong menjadi lambat, tetapi kelajuan motor pendorong masih melebihi motor pemotong singkong. Ketebalan singkong yang dihasilkan sebesar $8 \mathrm{~mm}$ dengan total waktu pemotongan 7 menit. Hasil potongan singkong diperlihatkan pada Gambar 6.

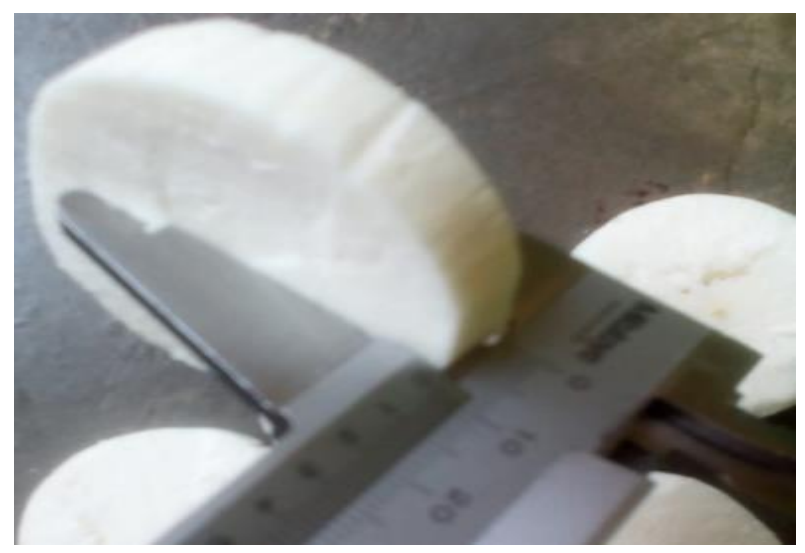

Gambar 6. Hasil pemotongan singkong untuk hambatan $800 \mathrm{k} \Omega$.

Potensiometer diputar pada posisi $900 \mathrm{k} \Omega$ berfungsi untuk mengurangi tegangan dari power supply ke motor sehingga kelajuan motor pendorong singkong menjadi lambat, tetapi kelajuan motor pendorong masih melebihi motor pemotong singkong. Ketebalan singkong yang dihasilkan sebesar $5 \mathrm{~mm}$ dengan total waktu pemotongan 9 menit. Hasil potongan singkong diperlihatkan pada Gambar 7.

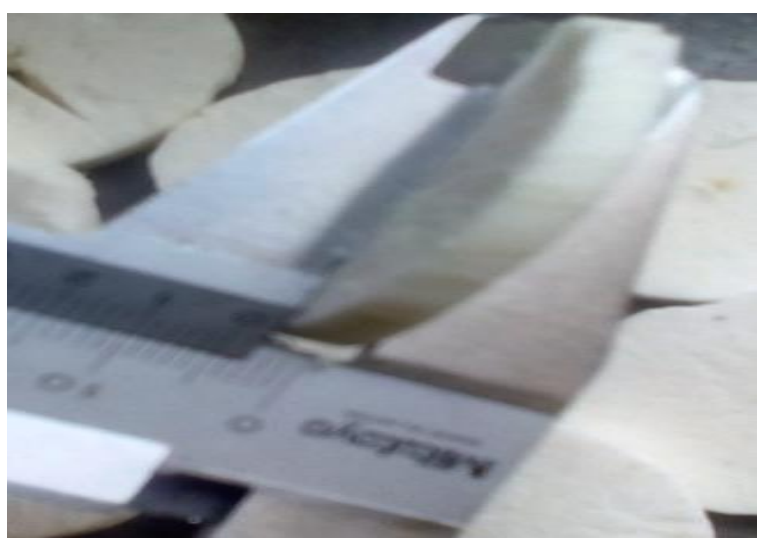

Gambar 7. Hasil pemotongan singkong untuk hambatan $900 \mathrm{k} \Omega$.

Potensiometer diputar pada posisi $1 \mathrm{M} \Omega$ berfungsi untuk mengurangi tegangan dari power supply ke motor sehingga kelajuan motor pendorong singkong menjadi lambat dan didapatkan ketebalan singkong hasil pemotongan sebesar 4 mm dengan total waktu pemotongan 12 menit. Hasil potongan singkong ditunjukkan pada Gambar 8. Hasil ini merupakan hasil yang paling optimal dari 5 eksperimen yang dilakukan dalam penelitian ini. 


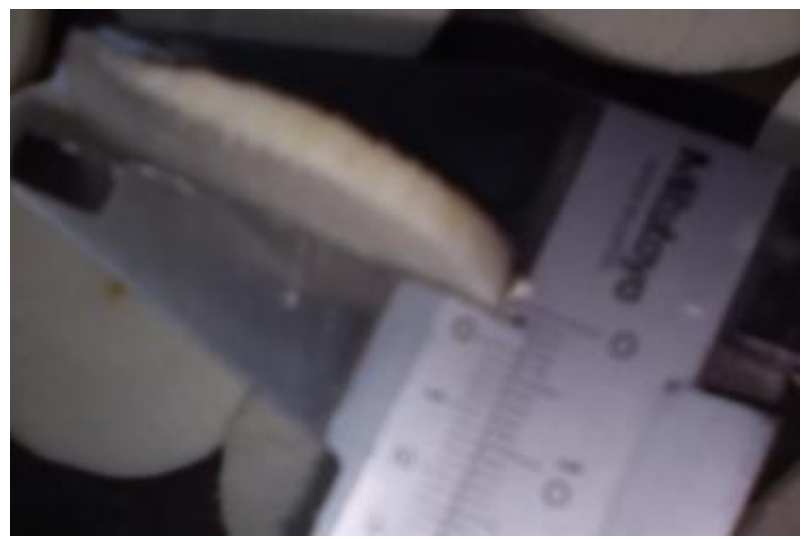

Gambar 8. Hasil pemotongan singkong untuk hambatan $1 \mathrm{M} \Omega$.

\section{KESIMPULAN}

Berdasarkan hasil dan analisis dari data yang sudah diperoleh dapat disimpulkan bahwa kondisi pemotongan singkong yang paling optimal pada saat hambatan potensiometer diputar pada posisi $1 \mathrm{M} \Omega$ dengan ketebalan yang didapat sebesar $4 \mathrm{~mm}$. Namun, kekurangannya waktu yang dibutuhkan masih sedikit lama. Sedangkan hasil pemotongan pada saat potensiometer diposisikan pada hambatan $800-900 \mathrm{k} \Omega$ didapatkan ketebalan yang tidak terlalu tipis yaitu dengan ketebalan berkisar 5-8 mm.

\section{DAFTAR PUSTAKA}

[1] Winandar, Nikolaus dan M. Hafidin. "Mesin Pemotong Singkong Automatis". Institut Teknologi Sepuluh Nopember, Surabaya. 2004.

[2] Hermanto, Bambang dan A. Setiyanto. "Modifikasi Mesin Pemotong Singkong Kontinu Dengan Hasil Potongan Berbentuk Oval dan Empat Persegi Panjang". Institut Teknologi Sepuluh Nopember, Surabaya. 2007.

[3] I. Magdalena dan D. E. P. Sardi. "Rancang Bangun Mesin Pemotong Singkong Dengan Menggunakan Metode Cam Follower". Institut Teknologi Sepuluh Nopember, Surabaya. 2011.

[4] A. Hidayatullah, dan N. Husodo. "Rancang Bangun Mesin Potong Singkong Menggunakan 6 Hopper dengan Metode Gerak Pemotongan Translasi Berpenggerak Motor Bensin". Institut Teknologi Sepuluh Nopember, Surabaya. 2016.

[5] H. Ma. "Fundamentals of Electronic Circuit Design". 2005. [Online]. Available: http://www-mdp.eng.cam.ac.uk/web/library/enginfo/ electrical/hong1.pdf. 